\title{
A FIRM LEVEL STUDY OF INFORMATION TECHNOLOGY PRODUCTIVITY IN EUROPE USING FINANCIAL AND MARKET BASED MEASURES
}

\author{
Alan R. Peslak, Ph.D. \\ Assistant Professor of Information Sciences and Technology \\ Penn State University - Worthington Scranton \\ 120 Ridge View Drive

ABSTRACT

For many years, business has invested significant resources in information technology, hardware, software, and manpower. The Productivity Paradox is the seeming lack of productivity gains despite the increased investment in IT. For many years the existence of a Productivity Paradox has been the subject of research interest. Conflicting results have been obtained from a variety of data sets. Until this time however there has been no study that has investigated European companies' use of information technology and its impact on productivity.

The objective of this study was to investigate information technology productivity with a new data set from a European published source, and measuring productivity using both market and financial based measures.

Results of the study indicated that information technology did have a consistent positive impact on firm level productivity in Europe for the years 1996, 1997, and 1998. Both market and financial based productivity measures provided consistent positive significant returns with regard to IT productivity.

The major contribution of the study is that it provides an analysis of the impact of European information technology on firm and economic productivity.

Since 1987, many researchers such as Erik Brynjolfsson, Paul Strassman, and Loren Hitt have studied the problem of whether the huge investment in information technology (IT) has had a positive impact on overall productivity in the economy and specifically on the firm. A variety of data sources has been analyzed across different perspectives and researchers have come to different conclusions on this central question.

The Productivity Paradox concept started in 1987 with Robert Solow, the Nobel prize-winning economist, who said that computers can be seen everywhere but in the productivity statistics (Solow, 1987). The Paradox as presented by Strassmann is that, despite large investments in information technology, productivity as measured by cost of goods sold has not increased (McCune, 1998). Loveman, in 1988, studied information technology capital versus output over a five-year period, and found no correlation between information technology spending and output increase (Brynjolfsson, 1993). The Productivity Paradox simply stated that empirical investigations in the late 1980s and early 1990s seemed to show that information technology investments, by a variety of measures, were not contributing to overall productivity gains. Since the late 1980 s, however, a series of studies have provided different, more positive results for information technology investments. The studies have included Brynjolfsson and Hitt (1996), Bharadwaj, Bharadwaj, and Knosynski (1999) and Dewan and Kraemer (1998).

\section{RELEVANCE OF THE STUDY}

The general question addressed in this research is similar to many previous studies, i.e., does investment in information technology have a significant positive effect on overall firm productivity and performance. This work, however, adds to the literature in several ways:

1. This empirical study analyzes both market based and financial productivity measures.

2. This research examines current information.

3. It includes European firms. 


\section{BARRIERS AND ISSUES}

As with any empirical research, the biggest challenge was to find an appropriate data source to empirically investigate the proposed research problem.

The first step in obtaining a data set was to review the data sets used by other researchers in the field. The data sources for the studies presented in the literature search vary from government sources to major publications' survey data, to private empirical surveys. A data set heretofore unanalyzed was the Top 100 IT spenders in Europe from the publication Information Strategy.

\section{HYPOTHESES TO BE INVESTIGATED}

This study empirically investigates the following research hypothesis: Positive productivity gains are recognized for both European firms, in the recent time frame, from information technology investment.

\section{SIGNIFICANCE OF THE STUDY}

This study represents a significant research issue due to the sheer size of information technology spending in the economy as a whole, and its expected positive impact on firm level productivity. The significance of the study is that $32.5 \%$ of all business capital investment is IT related, not including software and systems development. (Dos Santos, Peffers, and Mauer, 1993) This is a very significant expenditure for business. It should be determined whether IT increases productivity.

The study of the productivity impact of information technology on organizations started slowly. Though commercial applications for computer technology started in the late 1950s and accelerated through the 1960s and 1970s, there was little research on measuring the benefits gained from information technology spending. The implementation of management information systems and related technology were accepted in organizations through the perceived savings in manpower gained from automating clerical tasks such as payroll, accounts payable, and other financial applications. But beginning in the early 1980s, researchers tried to measure the impact that IT was having on the individual firm, in specific applications, and on the economy as a whole. No significant studies focusing on IT productivity were developed until the early 1980s. Then the pace of studies significantly accelerated and reached its peak in the period 1987-1995. Results from two decades of studies have resulted in little consensus on whether IT spending is having a significant favorable impact on individual firms or the economy as a whole.

\section{DATA COLLECTION}

As noted, the data source for this study was culled from a published source. Information Strategy, a United Kingdom publication, prepares an annual survey of the top 100 information technology spenders for European businesses. Data were obtained from this organization.

All IT expenditures and personnel information were supplemented with published financial data from Compustat and Standard and Poor's financial publications and databases. Least squares regression methods were used to determine the impact of information technology expenditures on firm productivity. Both market based and financial productivity measures were reviewed and tested prior to use. Specific financial and market based measures were determined through analysis of Compustat and other data sources, and included generally accepted measures such as return on sales, return on equity, Tobin's q, market value per share, and return on assets.

\section{APPROACH}

The approach of this study was an empirical analysis at the firm level using financial and market based measures. Firm level data were used since most researchers suggest it provides the most accurate indicator of information productivity in the economy as a whole. Macroeconomic studies are affected by other significant economic factors and deal only with aggregate data. Application 
level studies cannot be extrapolated to the economy as a whole. Firm level studies as performed by Brynjolffson and Hitt (1996, 1998a), Lehr and Lichtenberg (1999), and Kwon and Stoneman (1995) have proven the most reliable. This study uses the same methodology as a study by the author on US firms (Peslak, 2003)

The data were entered into separate Excel spreadsheets. Financial and market information was obtained from the Compustat Global database. The global database information was obtained through Nova Southeastern University and School of Computer and Information Sciences.

The information obtained from the Compustat global database was used to prepare the financial and market based performance measures. The information is noted in Table 1.

TABLE 1. COMPUSTAT DATA

\begin{tabular}{|l|l|l|l|}
\hline $\begin{array}{l}\text { General company } \\
\text { information }\end{array}$ & Financial data & Financial ratios & Market ratios \\
\hline Company name & Current assets & $\begin{array}{l}\text { Return on assets - } \\
\text { ROA }\end{array}$ & $\begin{array}{l}\text { Price/earnings ratio - } \\
\text { PE ratio }\end{array}$ \\
\hline Primary SIC code & Current liabilities & $\begin{array}{l}\text { Return on Equity - } \\
\text { ROE }\end{array}$ & \\
\hline Industry group & Total assets & $\begin{array}{l}\text { Return on investment } \\
- \text { ROI }\end{array}$ & \\
\hline Employees & Total long-term debt & 3 Year return \% & \\
\hline & Sales & & \\
\hline & Current liabilities & & \\
\hline & Cash flow & & \\
\hline & $\begin{array}{l}\text { Earnings } \\
\text { interest and taxes }\end{array}$ & & \\
\hline & Market data & & \\
\hline & Shares outstanding & & \\
\hline & Stock price & & \\
\hline
\end{tabular}

From these data other measures were calculated including

- $\quad$ Market value $=$ Shares outstanding X Market price

- Current ratio $=$ Current assets $/$ Current Liabilities

- $\quad$ Non-current assets $=$ Total assets - Current assets

- Capital Intensity = Sales / Capital

- IT spending as a percent of sales

- Tobin's q (defined in Chapter 1)

- Market to book ratio (market value/book value)

- Market to cash flow ratio (market value/cash flow)

- Debt to asset ratio (Debt/assets).

The financial measures were

- Return on assets

- Return on equity

- Return on investment

- $\quad$ EBIT -- earnings before interest and taxes

- Three-year return

- Cash flow.

Market based measures were

- Tobin's q.

- Market value

- Price/earnings ratio

- Market price to book ratio

- Price/cash flow per share. 
These served as the dependent variables, or IT productivity measures. The key independent variable was some measure of information technology expenditures.

For the regression analyses performed, linear equations were used for all analyses as well as the Cobb-Douglas production function for non-ratio analyses. Ordinary least squares regression analysis was performed on the data sets.

A new analysis was performed on the Information Strategy European database and global Compustat databases to determine whether similar productivity gains were recognized in the time period 1996 -- 1998 for European firms. The general form of the non-ratio equation was

Performance index $(\mathrm{x})=\mathrm{a}+\mathrm{b}$ Current Assets +

$$
\begin{aligned}
& \text { c Total Assets }+ \\
& \text { d Total Long-term Debt }+ \\
& \text { e Total Sales }+ \\
& \text { f Total IT Budget }+ \\
& \text { g Total Non-current Assets }+ \\
& \text { h Number of Employees. }
\end{aligned}
$$

The equation was

$\mathrm{x}=\mathrm{a}+\mathrm{b}$ CA $+\mathrm{c}$ TA $+\mathrm{d}$ TLTD $+\mathrm{e}$ TS + f ITBUD $+\mathrm{g}$ TNCA $+\mathrm{h}$ EMP.

The dependent performance measures were tested against these independent variables -- cash flow, earnings before interest and taxes, and market value. The Cobb-Douglas production function was used for these dependent variables. The equations were changed as follows:

$\begin{aligned} \text { Log Performance index }(\mathrm{x})= & \mathrm{a}+\mathrm{b} \log \text { Current Assets }+ \\ & \mathrm{c} \log \text { Total Assets }+ \\ & \mathrm{d} \log \text { Total Long-term Debt }+ \\ & \text { e log Total Sales }+ \\ & \text { f log Total IT Budget }+ \\ & \mathrm{g} \log \text { Total Non-current Assets }+ \\ & \mathrm{h} \log \text { Number of Employees. }\end{aligned}$

The equation was

$\log \mathrm{x}=\mathrm{a}+\mathrm{b} \log \mathrm{CA}+\mathrm{c} \log \mathrm{TA}+\mathrm{d} \log \mathrm{TLTD}+\mathrm{e} \log \mathrm{TS}+\mathrm{f} \log$ ITBUD $+\mathrm{g} \log \mathrm{TNCA}+\mathrm{h} \log$ EMP.

The dependent performance measures were tested against the noted independent variables $-\log$ cash flow, log earnings before interest and taxes, and log market value.

Ratios were also used on the Information Strategy database as performance measures. The form of the equation and the independent variables were as follows:

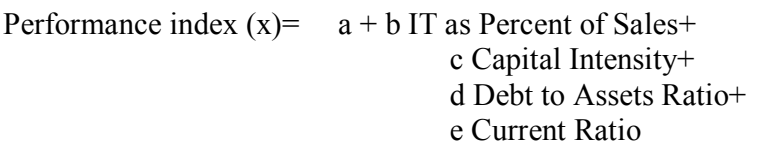

The equation was $\mathrm{x}=\mathrm{a}+\mathrm{b} \mathrm{IT}+\mathrm{c} \mathrm{CI}+\mathrm{d} \mathrm{DTA}+\mathrm{e} \mathrm{CR}$.

The following dependent performance measures were tested against these independent variables Market to Book ratio, Market to cash flow, PE ratio, ROA, ROE, ROI, Tobin's q, and 3 year return percent.

For the 14 performance measures tested, the overall adjusted $\mathrm{R}^{2}$ (coefficient of determination) was calculated as well as the IT variable correlation coefficient and its significance. A p value of .05 was used as the threshold for significance of the independent variable on the dependent performance measure. The significance of other independent variables was also reviewed. 
This analysis proceeded through each year of the Information Strategy data 1996, 1997, and 1998. The results were then reviewed to determine whether the results have been consistent for the period 1996-1998 for European firms.

\section{RESULTS}

The result tables use abbreviations for each dependent variable performance measure. The explanations of these abbreviations are shown in Table 2 .

Table 2. Performance Measures

\begin{tabular}{|l|l|l|}
\hline Abbreviation & Measure & Type of Measure \\
\hline 3YR & 3 Year Return & Financial \\
\hline CF & Cash Flow & Financial \\
\hline CFL & Log Cash Flow & Financial \\
\hline EB & Earnings Before Interest and Taxes & Financial \\
\hline LEB & Log Earnings Before Interest and Taxes & Financial \\
\hline LMV & Log Market Value & Market \\
\hline MV & Market Value & Market \\
\hline MTB & Market to Book Ratio & Market \\
\hline MTC & Market to Cash Flow Ratio & Market \\
\hline PE & Price/Earnings Ratio & Market \\
\hline ROA & Return on Assets & Financial \\
\hline ROE & Return on Equity & Financial \\
\hline ROI & Return on Investment & Financial \\
\hline TOB & Tobin's q Ratio & Market \\
\hline
\end{tabular}

The database from Information Strategy was assessed with the noted financial and market measures. The first year analyzed is shown in Table 3. In eight of the 13 measures, which could be tested, information technology expenditures were significant and positive. (One measure, market value log, was unable to be calculated because of insufficient data points). Total observations were fairly small however, at 13 to 16 observations. But for cash flow, market value, market to book value, return on assets, return on equity, return on investment, Tobin's q and 1-year return (3 year return was unavailable for the International database), significant and positive correlation coefficients were recorded. 
Table 3. 1996 Information Strategy European Summary

\begin{tabular}{|l|l|l|l|l|}
\hline Measure & Adj $R^{2}$ & Overall p & IT Coefficient & IT p Value \\
\hline CF & 0.938 & 0.0005 & 2.613 & 0.041 \\
\hline EB & 0.584 & 0.025 & 3.424 & 0.068 \\
\hline MV & 0.794 & 0.01 & 30.964 & 0.048 \\
\hline CFLOG & 0.987 & 0.081 & -3.169 & 0.131 \\
\hline EBLOG & 0.82 & 0.296 & -4.106 & 0.401 \\
\hline MVLOG & NA & NA & NA & NA \\
\hline MTB & 0.916 & 0.0005 & 51.782 & 0.0005 \\
\hline MTC & -0.35 & 0.878 & 74.838 & 0.672 \\
\hline PE & -0.404 & 0.926 & 7.046 & 0.992 \\
\hline ROA & 0.54 & 0.008 & 116.499 & 0.001 \\
\hline ROE & 0.337 & 0.061 & 218.133 & 0.011 \\
\hline ROI & 0.513 & 0.011 & 187.234 & 0.002 \\
\hline TOB & 0.921 & 0.0005 & 28.609 & 0.0005 \\
\hline 3YR & 0.348 & 0.056 & 1.278 & 0.012 \\
\hline
\end{tabular}

In the 1997 analysis of top European firms, the number of factors significant and positive was reduced, however. Only five of 14 were significant and positive at the $p<.05$ level. They were market to book, market to cash flow, Tobin's q, 1 year return, and return on assets. At the $p<.10$ level two more factors would be included, earnings before interest and taxes, and market value. Complete results are shown in Table 4. The number of data points rose to 22 to 26 depending on the dependent performance measure.

Table 4. 1997 Information Strategy European Summary

\begin{tabular}{|l|l|l|l|l|}
\hline Measure & Adj $^{2}$ & Overall p & IT Coefficient & IT p Value \\
\hline CF & 0.16 & 0.21 & -0.0966 & 0.974 \\
\hline EB & 0.713 & 0.0005 & 1.577 & 0.067 \\
\hline MV & 0.638 & 0.0005 & 15.358 & 0.075 \\
\hline CFLOG & -0.599 & 0.772 & 0.0793 & 0.967 \\
\hline EBLOG & -0.077 & 0.669 & -0.0249 & 0.988 \\
\hline MVLOG & 0.584 & 0.288 & 0.08213 & 0.946 \\
\hline MTB & 0.24 & 0.03 & 11.749 & 0.011 \\
\hline MTC & 0.623 & 0.0005 & 38.691 & 0.002 \\
\hline PE & 0.126 & 0.165 & 38.698 & 0.151 \\
\hline ROA & 0.379 & 0.003 & 27.911 & 0.0005 \\
\hline ROE & 0.103 & 0.154 & 7.381 & 0.797 \\
\hline ROI & 0.227 & 0.032 & 10.475 & 0.516 \\
\hline TOB & 0.439 & 0.001 & 8.806 & 0.0005 \\
\hline 3YR & 0.919 & 0.0005 & 2.106 & 0.0005 \\
\hline
\end{tabular}

The final year of the Information Strategy database available and analyzed was 1998. This year generally had 40-60 observations. Here, once again, there were eight measures that had significant $p$ values $($ at $\mathrm{p}<.05)$ for the information technology spending coefficients. The coefficients for cash flow, earnings before interest and taxes, market value, cash flow log, market to book, return on assets, return on investment, and Tobin's q all were positive. This suggests a positive correlation between information technology expenditures and the dependent performance measure. Another 
factor, return on equity, was positive and significant at the $\mathrm{p}<.10$ level. Complete details are shown in Table 5.

Table 5. 1998 Information Strategy European Summary

\begin{tabular}{|l|l|l|l|l|}
\hline Measure & Adj & Overall p & IT Coefficient & IT p Value \\
\hline CF & 0.886 & 0.0005 & 5.401 & 0.0005 \\
\hline EB & 0.754 & 0.0005 & 3.768 & 0.0005 \\
\hline MV & 0.356 & 0.0005 & 79.726 & 0.001 \\
\hline CFLOG & 0.795 & 0.0005 & 0.447 & 0.046 \\
\hline EBLOG & 0.755 & 0.0005 & 0.236 & 0.109 \\
\hline MVLOG & 0.17 & 0.155 & 0.539 & 0.193 \\
\hline MTB & 0.142 & 0.012 & 102.418 & 0.002 \\
\hline MTC & -0.077 & 0.937 & 56.737 & 0.632 \\
\hline PE & -0.065 & 0.865 & -14.153 & 0.922 \\
\hline ROA & 0.183 & 0.003 & 137.869 & 0.0005 \\
\hline ROE & 0.12 & 0.022 & 319.641 & 0.071 \\
\hline ROI & 0.253 & 0.0005 & 390.652 & 0.0005 \\
\hline TOB & 0.106 & 0.034 & 44.695 & 0.002 \\
\hline 3YR & -0.01 & 0.484 & 5.932 & 0.25 \\
\hline
\end{tabular}

Examining the European Information Strategy information, overall, from a financial versus market measure perspective results in Tables 6 and 7. Table 6 shows the European results for the 3 years for all financial measures. Twelve of the twenty-four analyses demonstrate strong positive relationships between information technology and the dependent performance measure significant at the $p<.05$ level. Of these, return on assets was positive and significant at the $p<.05$ level for all three years. 
Table 4-36. IS Financial European Summary

\begin{tabular}{|c|c|c|c|c|c|}
\hline Year & Measure & $\overline{A d j R^{2}}$ & Overall p & IT Coefficien & IT p Value \\
\hline 96 & $3 \mathrm{YR}$ & 0.348 & 0.056 & 1.278 & 0.012 \\
\hline 97 & $3 \mathrm{YR}$ & 0.919 & 0.0005 & 2.106 & 0.0005 \\
\hline 98 & $3 \mathrm{YR}$ & -0.01 & 0.484 & 5.932 & 0.25 \\
\hline 96 & $\mathrm{CF}$ & 0.938 & 0.0005 & 2.613 & 0.041 \\
\hline 97 & $\mathrm{CF}$ & 0.16 & 0.21 & -0.0966 & 0.974 \\
\hline 98 & CF & 0.886 & 0.0005 & 5.401 & 0.0005 \\
\hline 96 & CFLOG & 0.987 & 0.081 & -3.169 & 0.131 \\
\hline 97 & CFLOG & -0.599 & 0.772 & 0.0793 & 0.967 \\
\hline 98 & CFLOG & 0.795 & 0.0005 & 0.447 & 0.046 \\
\hline 96 & EB & 0.584 & 0.025 & 3.424 & 0.068 \\
\hline 97 & EB & 0.713 & 0.0005 & 1.577 & 0.067 \\
\hline 98 & EB & 0.754 & 0.0005 & 3.768 & 0.0005 \\
\hline 96 & EBLOG & 0.82 & 0.296 & -4.106 & 0.401 \\
\hline 97 & EBLOG & -0.077 & 0.669 & -0.0249 & 0.988 \\
\hline 98 & EBLOG & 0.755 & 0.0005 & 0.236 & 0.109 \\
\hline 96 & ROA & 0.54 & 0.008 & 116.499 & 0.001 \\
\hline 97 & ROA & 0.379 & 0.003 & 27.911 & 0.0005 \\
\hline 98 & ROA & 0.183 & 0.003 & 137.869 & 0.0005 \\
\hline 96 & ROE & 0.337 & 0.061 & 218.133 & 0.011 \\
\hline 97 & ROE & 0.103 & 0.154 & 7.381 & 0.797 \\
\hline 98 & ROE & 0.12 & 0.022 & 319.641 & 0.071 \\
\hline 96 & ROI & 0.513 & 0.011 & 187.234 & 0.002 \\
\hline 97 & ROI & 0.227 & 0.032 & 10.475 & 0.516 \\
\hline 98 & ROI & 0.253 & 0.0005 & 390.652 & 0.0005 \\
\hline
\end{tabular}

The market measures shown in Table 7 show similar strength in relationships between information technology expenditures in European firms and productivity. Nine of the seventeen analyses showed positive and significant $($ at $\mathrm{p}<.05)$ relationships. The Tobin's q measure was significant at $\mathrm{p}<.05$ and its correlation coefficient was positive in all three years analyzed. The results of the Information Strategy database thus confirm the conclusion that there is no significant difference between financial and market based measures in determining information technology productivity. 
Table 7. IS Market European Summary

\begin{tabular}{|l|l|l|l|l|l|}
\hline Year & Measure & AdjR $^{2}$ & Overall p & IT Coefficient & IT p Value \\
\hline 96 & MTB & 0.916 & 0.0005 & 51.782 & 0.0005 \\
\hline 97 & MTB & 0.24 & 0.03 & 11.749 & 0.011 \\
\hline 98 & MTB & 0.142 & 0.012 & 102.418 & 0.002 \\
\hline 96 & MTC & -0.35 & 0.878 & 74.838 & 0.672 \\
\hline 97 & MTC & 0.623 & 0.0005 & 38.691 & 0.002 \\
\hline 98 & MTC & -0.077 & 0.937 & 56.737 & 0.632 \\
\hline 96 & MV & 0.794 & 0.01 & 30.964 & 0.048 \\
\hline 97 & MV & 0.638 & 0.0005 & 15.358 & 0.075 \\
\hline 98 & MV & 0.356 & 0.0005 & 79.726 & 0.001 \\
\hline 96 & MVLOG & NA & NA & NA & NA \\
\hline 97 & MVLOG & 0.584 & 0.288 & 0.08213 & 0.946 \\
\hline 98 & MVLOG & 0.17 & 0.155 & 0.539 & 0.193 \\
\hline 96 & PE & -0.404 & 0.926 & 7.046 & 0.992 \\
\hline 97 & PE & 0.126 & 0.165 & 38.698 & 0.151 \\
\hline 98 & PE & -0.065 & 0.865 & -14.153 & 0.922 \\
\hline 96 & TOB & 0.921 & 0.0005 & 28.609 & 0.0005 \\
\hline 97 & TOB & 0.439 & 0.001 & 8.806 & 0.0005 \\
\hline 98 & TOB & 0.106 & 0.034 & 44.695 & 0.002 \\
\hline
\end{tabular}

Overall it can be stated that a significant positive relationship was generally established between information technology expenditures and European firm level productivity. The hypothesis was supported.

\section{CONCLUSIONS AND IMPLICATIONS}

The overall objective of the study was to determine whether a Productivity Paradox existed and currently exists at the firm level for European firms. In other words, the question was whether information technology had a positive impact on European firm level productivity. The results of the study generally found a positive relationship between IT spending and firm level productivity for European firms. A Productivity Paradox at the firm level was not observed in this study.

\section{ANTICIPATED BENEFITS}

The implications of the findings may influence corporate spending on information technology in Europe, since information technology expenditures generally added to the productivity of the European firm. Positive correlation between IT spending and productivity for European firms was found to exist. However, IT spending should be scrutinized closely. A relationship was found for European firms, but not all years and productivity measures were affected. Care must be taken with European IT expenditures. This study advances knowledge of the impact of information technology spending for current time frame, international analyses, using both financial and market based measures.

\section{REFERENCES}

Bharadwaj, A., Bharadwaj, S., and Knosynski, B. (1999). "Information Technology Effects on Firm Performance as Measured by Tobin's q", Management Science, Vol. 45 No.6, pp. 10081024. 
Brynjolfsson, E. (1993). "The Productivity Paradox of Information Technology", Communications of the ACM, Vol. 36 No.12, pp. 67-77.

Brynjolfsson, E. and Hitt, L. (1996). "Paradox lost? Firm-level Evidence on the Returns to Information Systems Spending", Management Science, Vol. 42 No.4, pp. 541-558.

Brynjolfsson, E. and Hitt, L. (1998). "Beyond the Productivity Paradox", Communications of the ACM, Vol. 41 No.8, pp. 49-55.

Kwon, M. and Stoneman, P. (1995). "The Impact of Technology Adoption on Firm Productivity", Economic Innovation and New Technology, Vol. 3, pp.219-253.

Lehr, B., and Lichtenberg, F. (1999, April). "Information Technology and its Impact on Productivity: Firm-level Evidence from Government and Private Data Sources, 19771993”, The Canadian Journal of Economics, Vol. 32 No. 2, pp. 335-362.

McCune, J. (1998, March). "The Productivity Paradox", American Management Association International, pp. 38-40.

Peslak, A. (2003, Summer). "IT Productivity in US Using Financial and Market Based Measures", Journal of Computer Information Systems, Vol. 43 No.4, pp. 72-80.

Solow, R. (1987, July 12). "We'd Better Watch Out", The New York Times, pp. 36.

Tam, K. (1998, March). "The Impact of Information Technology Investments on Firm Performance and Evaluation: Evidence from Newly Industrialized Economies", Information Systems Research, Vol. 9 No.1, 85-98. 